\title{
An Introduction to "Microbial Biogeochemistry: A Special Issue of Aquatic Geochemistry Honoring Mark Hines"
}

\author{
W. Berry Lyons ${ }^{1} \cdot$ David J. Burdige ${ }^{2}$
}

Published online: 22 May 2020

(c) Springer Nature B.V. 2020

This issue of Aquatic Geochemistry is dedicated to the memory of Dr. Mark E. Hines (Fig. 1) and his contributions to the fields of microbial biogeochemistry and aquatic geochemistry. Mark passed away in March of 2018, and through his career as a researcher, teacher, mentor, colleague, and university administrator, he greatly influenced the lives of all around him. We hope that this volume will serve not only as a memory of Mark, but also as a way to recognize his significant influences and major contributions in the fields of carbon, sulfur, and trace element biogeochemistry.

Mark received his BS from the Ohio State University in 1973, his MS from the University of Connecticut in 1978, and his Ph.D. from the University of New Hampshire in 1981, with all degrees in Microbiology. After the awarding of his Ph.D., Mark stayed on at the University of New Hampshire from 1981 to 1995 as a research staff member and then a research faculty member. He moved to the University of Alaska, Anchorage in 1995, and was a faculty member there until 2002. From that time onward until his death, he was a member of the Dept. of Biological Sciences at University of Massachusetts, Lowell, being promoted to Full Professor in 2005, and serving as department chair from 2004 to 2011. Beginning in 2011 he was appointed the acting Dean, and then the Dean of the Kennedy College of Science at UML. At both UAA and UML, he won university awards for his research prowess.

Mark was an internationally recognized leader in the field of microbial biogeochemistry. He published $\sim 10$ peer-reviewed journal articles and book chapters. The majority of these papers are published in the best geochemical and applied/environmental microbiological journals, including Global Biogeochemical Cycles, Applied and Environmental Microbiology, Applied Geochemistry, Chemical Geology, and Environmental Science and Technology. Fourteen (14) of his papers have over 100 citations, and his most highly cited paper "Anaerobic metabolism: linkages to trace gases and aerobic processes" in the 2003 Treatise on Geochemistry has 515 citations (Megonigal et al. 2003). One of his earliest papers, which came from his Ph.D. research, was a first author paper in Nature (Hines et al. 1982).

Mark was one of the first to use radiolabeled sulfur to determine bacterial sulfate reduction rates in sediments and to quantify the different microbial pathways of methane

David J. Burdige

dburdige@odu.edu

1 School of Earth Sciences, The Ohio State University, Columbus, OH, USA

2 Department of Ocean, Earth and Atmospheric Sciences, Old Dominion University, Norfolk, VA, USA 


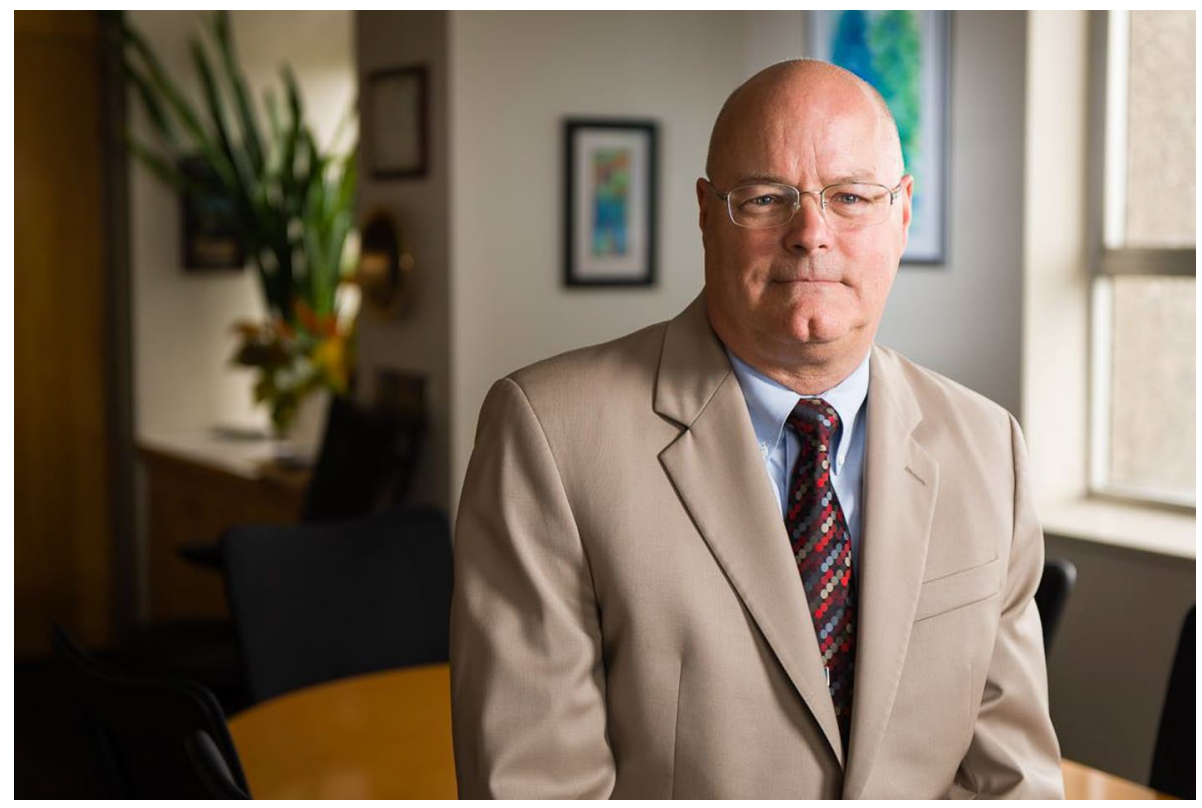

Fig. 1 Professor Mark Hines (1950-2018)

production, especially in bogs, salt marshes, and peatlands. This work is exemplified by papers such as Hines and Jones (1985), de Mello and Hines (1994), Hines et al. (1999), Duddleston et al. (2002), and Chanton et al. (2008). He also worked on such topics as ferrous-iron reduction in marine sediments (Tugel et al. 1986) and bromide methylation (Shorter et al. 1995). He was a world leader in investigating the methylation and demethylation of mercury, especially in mining wastes, with publications on this topic from many locations worldwide, including Slovenia (Hines et al. 2000), Spain (Gray et al. 2004), Brazil (Bonzongo et al. 2002), as well as the USA (Gray and Hines 2009; Gray et al. 2014). Mark was interested in just about everything that touched on the impact of microbes on geochemistry. He was known for both his experimental approach and design, as well as his rigor in the field. He was innovative as well as a stickler for precision and repeatability in both his experimental and field endeavors.

Mark was not only an excellent scientist and researcher, but also a great teacher and mentor of young scientists. He was a truly outstanding colleague and friend. This is clearly evidenced by the long-term collaborators that he published with for many decades that include such people as Ron Kiene, Jeff Chanton, Tamar Barkay in the USA and Jadran Fageneli in Slovenia, to name but a few (Note that this list also includes many of the authors of papers in this volume!). His passion for science was equal to his lust for life, which was contagious to all who interacted with him. His gift for storytelling, and his ability to find something humorous in every situation was extraordinary, and he made all to feel worthy of his unusual warmth.

The papers in this special issue were all written by friends and colleagues of Mark and cover a wide range of topics, many of which were central to Mark's work over his lifetime. In addition to the good science contained in these papers, their acknowledgments also contain moving testaments about how Mark touched all of our lives in so many different ways. Lastly, please note that two of the papers submitted to this special issue (Kelley et al. 2019; Klun et al. 2019) were inadvertently published in a regular issue of Aquatic Geochemistry in late 2019 
(vol. 25 number 5-6). However, they are also listed here in the Table of Contents of this special issue since they most certainly belong in this collection.

In describing Mark, one of us (WBL) once explained that he was a man of very many talents, and one who could have been successful in almost any endeavor he undertook. People loved working with him, and being around him, in general, and his scientific acumen was rivaled only by his people skills. He is, and will continue to be, sorely missed by all of us who knew him and were influenced by him.

\section{References}

Bonzongo JC, Lyons WB, Hines ME, Warwick JJ, Faganeli J, Horvat M, Lechler PJ, Miller JR (2002) Mercury in surface waters of three mine-dominated river systems: Idrija River, Slovenia; Carson River, Nevada; and Madeira River, Brazilian Amazon. Geochem Explor Environ Anal 2:111-119

Chanton JP, Glaser PH, Chasar LS, Burdige DJ, Hines ME, Siegel DI, Tremblay LB, Cooper WT (2008) Radiocarbon content of fermentation and respiration products and molecular composition of dissolved organic carbon in boreal peatlands in relation to the solid-phase peat. Glob Biogeochem Cycles 22:4022

de Mello WZ, Hines ME (1994) Application of static and dynamic enclosures for determining dimethyl sulfide and carbonyl sulfide exchange in Sphagnum peatlands: implications for the magnitude and direction of flux. J Geophys Res Atmos 99:14601-14607

Duddleston KN, Kinney MA, Kiene RP, Hines ME (2002) Anaerobic microbial biogeochemistry in a northern bog: acetate as a dominant metabolic end product. Glob Biogeochem Cycles 16:1063

Gray JE, Hines ME (2009) Biogeochemical mercury methylation influenced by reservoir eutrophication, Salmon Falls Creek Reservoir, Idaho, USA. Chem Geol 258:157-167

Gray JE, Hines ME, Higueras PL, Adatto I, Lasorsa BK (2004) Mercury speciation and microbial transformations in mine wastes, stream sediments, and surface waters at the Almadén Mining District. Spain Environ Sci Technol 38:4285-4292

Gray JE, Hines ME, Goldstein HL, Reynolds RL (2014) Mercury deposition and methylmercury formation in Narraguinnep Reservoir, southwestern Colorado, USA. Appl Geochem 50:82-90

Hines ME, Jones GE (1985) Microbial biogeochemistry in the sediments of Great Bay, New Hampshire. Est Coast Shelf Sci 20:729-742

Hines ME, Orem WH, Lyons WB, Jones GE (1982) Microbial activity and bioturbation-induced oscillations in pore water chemistry of estuarine sediments in spring. Nature 299:433-435

Hines ME, Evans RS, Sharak Genthner BR, Willis SG, Friedman S, Rooney-Varga JN, Devereux R (1999) Molecular phylogenetic and biogeochemical studies of sulfate-reducing bacteria in the rhizosphere of Spartina alterniflora. Appl Environ Microbiol 65:2209-2216

Hines ME, Horvat M, Faganeli J, Bonzongo J-CJ, Barkay T, Major EB, Scott KJ, Bailey EA, Warwick JJ, Lyons WB (2000) Mercury biogeochemistry in the Idrija River, Slovenia, from above the mine into the Gulf of Trieste. Environ Res 83:129-139

Kelley CA, Bebout BM, Chanton JP, Detweiler AM, Frisbee A, Nicholson BE, Poole J, Tazaz A, Winkler C (2019) The effect of bacterial sulfate reduction inhibition on the production and stable isotopic composition of methane in hypersaline environments. Aquat Geochem 25:237-251

Klun K, Falnoga I, Mazej D, Šket P, Faganeli J (2019) Colloidal organic matter and metal(loid)s in coastal waters (Gulf of Trieste, Northern Adriatic Sea). Aquat Geochem 25:179-194

Megonigal JP, Hines ME, Visscher PT (2003) 8.08-Anaerobic metabolism: linkages to trace gases and aerobic processes. In: Holland HD, Turekian KK (eds) Treatise on Geochemistry. Pergamon, Oxford, vol 8, pp $317-424$

Shorter JH, Kolb CE, Crill PM, Kerwin R, Talbot R, Hines M, Harriss R (1995) Rapid degradation of atmospheric methyl bromide in soils. Nature 377:717-719

Tugel JB, Hines ME, Jones GE (1986) Microbial iron reduction by enrichment cultures isolated from estuarine sediments. Appl Environ Microbiol 52:1167-1172

Publisher's Note Springer Nature remains neutral with regard to jurisdictional claims in published maps and institutional affiliations. 